\title{
Current Account and International Networks
}

Daryna Grechyna

\section{ThE PAPERS}

DPTO. TEORÍA E HISTORIA ECONÓMICA WORKING PAPER SERIES UNIVERSIDAD DE GRANADA 
Current Account and International Networks

Daryna Grechyna

$19 / 08$

Daryna Grechyna (2019). Current Account and International Networks. ThE Papers, Department of Economic Theory and Economic History of Universidad de Granada. 19/08. 


\title{
Current Account and International Networks
}

\author{
Daryna Grechyna*
}

\begin{abstract}
This paper explores the impact of international financial and trade networks on current account balances in a large sample of developing and developed countries. The financial and trade inter-country networks centrality measures are computed based on the quantity and strength of the financial assets flows (for financial network) or export flows (for trade network) among the countries. I rely on a panel data and employ the fundamental characteristics of a country's trading partners as instruments for the position of a given country in the international networks. I find that a more central position in the international trade or financial network improves the current account balance in developed and developing countries. Besides, the impact of international financial network on current account has become stronger over the past two decades and a better position in this network helped improve the current account balances during the Great Recession.
\end{abstract}

Keywords: current account; international financial network; international trade network; panel data.

JEL Classification Numbers: F32, F41, F42.

*Departamento de Teoría e Historia Económica, University of Granada, Facultad de Ciencias Económicas y Empresariales, Campus Universitario de Cartuja P.C 18071, Granada; E-mail: dgrechna@gmail.com. 


\section{Introduction}

The world economy is becoming increasingly interconnected. Recent waves of trade liberalization, financial deregulation, and technological advances have facilitated growth in international flows of goods, services, and financial assets. At the same time, diverse economic and financial development paths of countries comprising the global economy have contributed to the current account imbalances (see Caballero et. al., 2008). In particular, a given country's current account position is significantly affected by the degree of its involvement in the global economy, as measured by its openness to international trade and its financial development level (Chinn and Ito, 2007). In the scope of increasing globalization, international trade and financial networks have emerged as important drivers of a number of international economic phenomena, including financial contagions and systemic risk spread (see, for example, Gai and Karadia, 2010 and Kali and Reyes, 2010). The question arises whether a country's position in these international networks has any impact on its current account, above and beyond the traditional measures of trade openness and financial development. This question is of significant policy importance: given recent concerns about the tendencies of growing gross international flows and current account imbalances, understanding the role of international connections in these processes could facilitate the elaboration of policies aimed at improving international financial stability.

The purpose of this paper is to investigate the relationship between a country's position in the international trade and financial networks and its current account balance. The international trade network (ITN) is represented by the structure of trading links and volumes of export flows among the countries. The international financial network (IFN) is represented by the structure of foreign investment links and financial assets flows among the countries. These networks reflect both the state of the global macroeconomy (described by the structure of the network) and the role of each particular country in the international economic system (described by the characteristics of individual countries relative to other countries in the network). Is being an important country in the international networks good for current account balance? On the one hand, a country which is central in the international network is connected to many other countries and/or these links are important for the other countries (because of large exports or financial flows, or because a central country serves as a bridge between the other countries' trade). Therefore, such a country can potentially better diversify risks from foreign and domestic activities by manipulating its trade or financial flows to its international partners. On the other hand, being a key player in the international network of assets or flows of goods and services implies higher exposure to trade or financial shocks from the trading 
partners. Therefore, the effect of being more central in the international financial and trade networks on current account of a country is ambiguous in general. Besides, the impact of international networks on current account can differ along a country's development path and across countries over time.

I rely on a panel data for a large sample of developed and developing countries and on the econometric specifications used in the panel estimation literature on current account determinants (see, for example, Chinn and Prasad, 2003; Chinn and Ito, 2007; Gruber and Kamin, 2007 and 2009; Chinn et al., 2013; Behringer and van Treeck, 2018) to evaluate the role of ITN and IFN position on the current account across countries and over time, for developed and developing country groups. In all estimations, I control for a standard set of current account determinants, such as the net foreign assets position, population dependency ratios, economic output and its growth rate, openness and financial development, oil rent, fiscal balance, and terms of trade volatility.

The main obstacle in the analysis of the role of international networks on the current account is the simultaneity of the position in the network and the stage of economic development. Advanced industrial economies have more developed financial systems, and are in general more important in the networks of international financial and trade linkages. Moreover, a country's position in the international trade network, its fiscal balance, and its current account can be driven by the same unobserved factors, and there is a potential feedback from the state of current account to the country's trade and financial links to other countries. To overcome these problems, I include the interaction of developing countries dummy with the international network variable and I use an instrumental variable approach to purge off the endogenous component of the network variables and fiscal balance. Following the network literature (see, for example, Bramoulle et al., 2009 and Aller et.al., 2015), the instruments I consider for international network position are the fundamental characteristics of a country's trading partners, such as country's trading partners' population size and country's geographical distance to trading partners or to trading partners' partners. Following Chinn and Ito (2007) and Behringer and van Treeck (2018), I instrument the fiscal balance using the unemployment rate, average country's fiscal balance over time, and polity index.

The results based on several estimation techniques suggest that a more central position in the international trade or financial network improves the current account. In particular, a one percent increase in the network centrality of a developed country leads to around one percent increase in its current account share of output (GDP). For developing countries, being more central in the international trade network can worsen the current account, while being more 
central in the international financial network unambiguously improves the current account.

Besides, I find some evidence that the impact of international financial network position of a country on its current account balance has being gradually increasing over time. In particular, having a one percent more connections or one percent larger volumes of financial flows had twice as large impact on current account after the Great Recession as at the beginning of 2000s. The impact of international trade networks remained constant over the last two decades for developed countries and declined for developing countries.

Finally, the estimates from the baseline model suggest that greater degree centrality or strength in the international financial networks helped improve the current account balances during the Great Recession.

The remainder of the paper is organized as follows. Section 2 reviews the related literature. The theoretical background behind the potential relationship between the inter-country networks and current account balances is discussed in Section 3. Section 4 describes the data sources and methods used to construct the ITN, IFN, and individual countries' centrality measures in these networks. Section 5 explains the empirical methodology used to analyze the relationship between current account and network centrality measures. Section 6 presents and discusses the estimation results. Section 7 concludes the paper.

\section{Related Literature}

This study contributes to two growing streams of literature: on the determinants of current account balances and on the role of international networks in macroeconomy. Chinn and Prasad (2003) performed an extensive analysis of the potential correlates of the current account using various time intervals that cover medium and long term. The fiscal balance, initial stock of net foreign assets, relative income, economic growth rate, population structure, trade openness, and financial deepening were identified as proximate determinants of current account. The models by those authors have been extended to evaluate the impact of financial development, financial crises, and institutional variables on the current accounts (see Chinn and Ito, 2007; Chinn et al., 2013; Gruber and Kamin, 2007 and 2009). Ranciere et al. (2012) and Behringer and van Treeck (2018) have analyzed the impact of income inequality on current account deficit and found that income inequality measured by top income shares, together with financial liberalization, contributes to current account deficits in high-income economies. The housing market (reflected in the rising equity and real estate prices and household leverage) has emerged as another potential determinant of the current account balance in recent decade (as discussed, 
for example, by Chinn et. al., 2013; Aizanman and Jinjarak, 2009; and Fratzscher and Straub, 2009). Calderon et al. (2002) discuss how the global economy affects developing countries current account balances through the international capital flows which intensify with higher growth rates in industrialized countries or lower international interest rates. Given a significant amount and variety of the potential current account determinants, Ca'Zorzi et al. (2012) have checked their robustness using a number of specifications accounting for model uncertainty. Their findings in general support the inclusion of the set of standard determinants (such as those considered by Chinn and Prasad, 2003) in the current account models. In this paper, I rely on the baseline specification by Chinn and Prasad (2003) and related studies, and I introduce the variables reflecting a country's position in the international trade and financial networks to evaluate the effect of these networks, if any, on the current account.

While trade openness and financial development have been identified as important drivers of international current account imbalances, the role of intentional trade network and international financial network in current account has not been clarified. At the same time, a vast literature discusses the importance of these networks for international financial stability and international contagion during crises, concepts which are very closely related to global current account imbalances. In the next section, I discuss theoretical foundations behind the potential direct and indirect impact of international networks on the current account, based on the common hypotheses about the dynamics of current account: the intertemporal approach (see Obstfeld and Rogoff, 1995); the "stages of development" hypothesis (see Chinn and Prasad, 2003); and the "global saving glut" hypothesis (see Bernanke, 2005 and Caballero et al., 2008).

International financial networks have been mainly considered in the scope of the theories of systemic risk, contagion, and financial crises. In particular, the structure of international financial network has been shown to affect the stability of economic systems (see, for example, Allen and Gale, 2000; Gai and Karadia, 2010; and Nier et al., 2007). The empirical studies on the role of international financial networks have been restricted by data availability. Two most comprehensive datasets on the financial assets linkages among the countries are the Coordinated Portfolio Investment Survey (CPIS) on country's holdings of portfolio investment securities by the International Monetary Fund (IMF) and locational statistics on exchange-rate adjusted cross-border bank credit by the Bank of International Settlements. These datasets have been used to analyze the characteristics of the international financial network before and after the 2008 financial crisis (see, for example, Chinazzi et. al., 2013 and Minoiu and Reyes, 2013 for the analysis of IMF and BIS data, respectively). The focus of this paper is on the country-level 
phenomena of current account and global imbalances. Therefore, I use the CPIS country-level data on holdings of portfolio investment securities from the IMF to construct the international financial network. I use the network centrality measures, constructed given the information on the flows of investment securities among the individual countries, as measures of the importance of individual countries in the international financial network.

The network structure of the international trade flows has been extensively analyzed (see, for example, Fagiolo et al., 2009 and 2010; De Benedictis and Tajoli, 2011). Similar to the international financial network, international trade network has been used to explain financial contagion (see, for example, Glick and Rose, 1999; Kali and Reyes, 2010). Besides, the international trade network centrality measures has been shown to contribute to inter-country externalities such as carbon dioxide levels in the environment (see Aller et. al., 2015). Following the existing studies, I use the centrality measures constructed given the information on links and volumes traded among the individual countries as measures of the importance of individual countries in the international trade network.

It has been recognized that the financial and trade networks are interrelated. In particular, Ding et al. (2019) analyze the relationship between the two international networks and argue that these networks are interrelated in the long run. Moreover, the international financial network has predictive power on the trade network in the short run. Schiavo et. al. (2010) study the topological structure and the properties of the international trade and financial networks, using measures of centrality to account for the indirect effects of trade and capital flows. In this paper, I follow a similar approach to analyze the impact of international networks on the current account. The next section discusses the theoretical foundations behind the existence of such an impact.

\section{Theoretical Background}

It is difficult to explain the dynamics of current account observed in different countries and over time by a single theory. The intertemporal approach to the current account views the current-account balance as the outcome of forward looking dynamic saving and investment decisions (see Obstfeld and Rogoff, 1995). The individuals use their savings to smooth the impact of transitory shocks originating in their country. The international markets facilitate such risk sharing. Besides, the diversity of country-specific characteristics such as public policy (e.g., tax rates and the time preferences), population structure (and thus, preferences to save), and trade policy (existence of tariffs or quotas, and thus, the degree of openness) can to some 
Figure 1: Current account by country development stage.

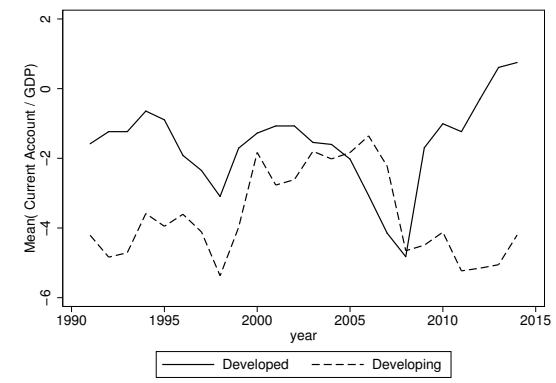

Note: This figure shows the current account balances averaged over developed (solid line) and developing (dashed line) countries, for time period 1991-2014. Data Source: World Bank.

degree explain the variety of current account balances in the global economy.

The division of the world economy into groups of countries with different development levels further contributes to the global current account imbalances. The "stages of development" hypothesis for the balance of payments suggests that less developed countries tend to import capital and, therefore, run current account deficits (see Chinn and Prasad, 2003). Figure 1 presents the average current account balance as a share of GDP over 1991-2014 for country groups characterized by different development levels. The current account deficit is more pronounced for developing countries compared to developed countries, consistent with the "stages of development" hypothesis.

The opposing view, first stated by the Lucas (1990), suggests that capital flows from poor countries into rich rather that the other way round. Recently, Bernanke (2005) initiated discussion about the causes and consequences of the "global saving glut", the term used to refer to growing supply of savings from developing countries observed at the end of the XX century. The theoretical foundations for this phenomenon have been provided by Caballero et al. (2008) who have shown that the differences in economic growth rates and financial development levels can explain a significant fraction of global current account imbalances observed at the end of XX century.

The impact of the economic growth rates and financial development levels on current account has been diligently investigated in a number of empirical studies. For example, Chinn and Ito (2007) argue that greater financial development leads to higher savings and improve current account, but the evidence is not sufficient to support the "global saving glut" hypothesis. Similarly, Gruber and Kamin (2009) find that traditional financial development measures do not explain the current account surpluses in developing countries or the large U.S. deficit.

This paper contributes to the discussion by analyzing the role of international trade and 
financial network measures that can account for both direct and indirect effect of financial development and trade openness on the current account balances. The direct effect is expected to be similar to that from the standard measures of financial development and trade openness, because the more financially developed or open to trade a country is, the more it is interconnected with other countries and the more important it is in the international financial and trade networks.

The indirect effect on current account originates from the global structure of the international networks. A given country's response to economic shocks depends not only on this country's internal characteristics (such as fiscal policy or population structure), economic conditions, and its connectedness with the rest of the world, but also on the characteristics and economic conditions of its trading partners, trading partners' partners, and the whole trading network.

In order to understand the role of the international network in smoothing or amplifying economic fluctuations, consider an artificial world economy which consists of five countries and where the international connections among the countries are represented by network shown in Figure 2. The nodes $a, b, c, d$, and $e$ represent countries, and the lines connecting these nodes represent connections among these countries (for example, export flows in the case of international trade network or capital flows in the case of international financial network). Note that country $e$ is connected to country a directly, and to the other countries indirectly, through country $a$. Countries $a, c$, and $d$ are directly connected to two countries each and indirectly, through country $b$, to the other two countries in the network. Country $c$ is directly connected to three countries, $a, c$, and $d$, and indirectly to country $e$. Given that $b$ has the largest number of direct neighbors, it is the most central country in the network. Moreover, given that the connections between $c$ or $d$ and $a$ or $e$ are only possible through $b$, it also serves as an important bridge for international relations among the other countries, thus being a critical player in the network.

How the centrality or criticality of a country in the international network can affect this country's current account? Suppose country e suffers from a domestic negative economic shock. It can use its international connections to smooth the negative impact of this shock, for example, by borrowing from its trading partners. It is more likely that $e$ will use $a$ for these purposes, given that it is its closest trading partner. If $a$ itself is in bad economic conditions, it can be difficult for $e$ to cushion the effect of negative shock using the international markets. It may have to offer higher return to be able to borrow from more distant neighbors $(b, c$, or $d)$, and thus, can suffer a more severe decline in the current account balance than a country that is 
Figure 2: An example of the international network of countries in a model economy.

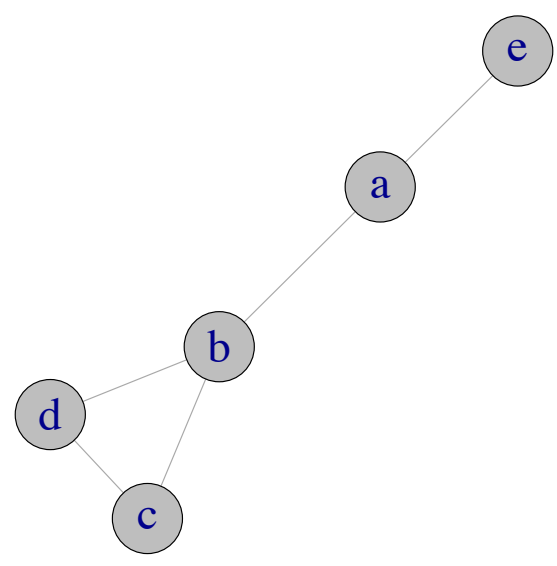

Note: This figure shows an example of an inter-country network in a model economy; circles represent countries and lines connecting the circles represent international relations between countries.

better connected to other countries, such as country $b$.

However, the impact of the international network is not restricted to the bilateral relationships. Suppose, at the same time when country $e$ experiences a negative shock, country $b$ also has turbulent economic times. Given that country $b$ is well-connected, it can reduce the negative consequences of its shock using economic relationships with $c, d$, or $a$; it can also propagate its domestic shocks to these countries through reduction in trade or expected investment flows. In the latter case, the most negatively affected country, with the largest change in the current account balance, could be country $a$, because it is directly connected to both $b$ and $e$. Besides, the waves of secondary effects from $c, d$ and $a$ on $b$ and $e$ could further magnify or mitigate the impact of the original shocks. Kali and Reyes (2010) and Aller et al. (2015) discuss similar examples and provide additional intuition on the indirect effect of international networks on economic indicators of a given country.

Thus, the position of a country in the international trade or financial network, directly and indirectly, can affect its current account balance by influencing the ability of this country's residents to smooth consumption (the intertemporal approach to current account); the ability to invest domestic capital abroad or to attract foreign capital (the "stages of development" hypothesis); or the ability to save because of precautionary motives (the "saving glut" hypothesis).

In this paper, I account for the fact that in two countries characterized by the same structure 
of international connections, the impact of these connections on the current account can depend on the level of economic development of a country. The reaction of trading partners on a change in economic conditions of a given country may depend on the speed of response by the private and public sector and on the state of institutions in that country as well as on the level of credibility of a given country from the point of view of its potential lenders.

I conduct empirical analysis distinguishing between developed and developing countries to account for these possibilities. The data used to construct international networks and the measures of countries' importance in the network are described in the next section.

\section{The Data}

This section describes the data sources and methods used to construct the international trade network (ITN), the international financial network (IFN), and the measures of individual countries importance in these networks (network centrality measures). It also presents some basic descriptive statistics about the constructed network measures and their correlation with the current account in different country groups.

The international trade network is computed based on the data on bilateral trade flows between countries available for 1870-2014 from the Correlates of War Project (Barbieri et al., 2009 and 2016). The international financial network is computed based on the cross-border holdings of portfolio investment securities data available for 2001-2017 from the Coordinated Portfolio Investment Survey (CPIS) by the IMF. The flows of trade and assets are bi-directional: each country is characterized by inflows (imports for trade, being a holder of security for financial assets) and outflows (exports or being an issuer of financial securities that are invested in another country), where the inflows and outflows can be positive or zero.

I concentrate on the network of outflows, because it approximates the potential ability of a country to spread risk given that the outflows can be decided within a country (this approach is common in the literature, see, for example, Kali and Reyes, 2010 and Aller et al., 2015). The networks that are based on inflows or on total bi-directional flows (inflows and outflows) have similar characteristics to the networks based on outflows: the correlation coefficients among the constructed network characteristics are greater that 0.50 , on average.

Define the international trade network at time $t, G_{t}^{T}$, as a weighted-directed graph where nodes are $N_{t}^{T}$ countries joined by directed links, $s_{a b, t}^{T}$, that connect the country-exporter $a$ to the country-importer $b$, with the weights, $w_{a b, t}^{T}$, being the export volumes from the exporter to the importer. Given this notation, $s_{a b, t}^{T}=1$ if $a$ exports to $b$ at time $t$ and zero otherwise and 
$w_{a b, t}^{T} \geq 0$.

Similarly, define the international financial network at time $t, G_{T}^{F}$, as a weighted-directed graph where nodes are $N^{F}$ countries joined by directed links, $s_{a b, t}^{F}$, that connect the issuing country $a$ to the holder of the security $b$ and the weights, $w_{a b, t}^{F}$, are the value of securities held by the issuing country. Given this notation, $s_{a b, t}^{F}=1$ if $a$ invests in $b$ at time $t$ and zero otherwise and $w_{a b, t}^{F} \geq 0$.

In network terminology, there is a path between $a$ and $b$ in $G_{t}^{i}, i \in\{T, F\}$, if there exists a sequence of edges that connects nodes $a$ and $b$, that is, $w_{a b, t}^{i} \neq 0$.

Following related studies on international trade and financial networks (e.g., Chinazzi et. al., 2013; Minoiu and Reyes, 2013; Fagiolo et al., 2009, 2010; De Benedictis and Tajoli, 2011; and Aller et al., 2015), I use the centrality measures from network analysis to characterize the position and importance of a country in the international networks. In particular, I consider each country as a node in the international network and compute the following variables for every country in every time period:

- Degree centrality, $D_{a, t}^{i}, i \in\{T, F\}$, of country a at time $t$, is defined as the number of outcoming links connected to a given country (the number of countries that import from a given country in the case of ITN, $i=T$, and the number of countries in which a given country invests in the case of IFN, $i=F$ ). Formally,

$$
D_{a, t}^{i}=\sum_{b \neq a \in G_{t}^{i}} s_{a b, t}^{i}, i \in\{T, F\} .
$$

Thus, degree is the number of nodes at distance one. This is the simplest centrality measure, reflecting the importance of a country measured by its involvement in international interactions.

- Strength, $S_{a, t}^{i}, i \in\{T, F\}$, of country $a$ at time $t$, is defined as the sum of weighted outcoming links connected to a given country (the number of countries that import from a given country weighted by the volume of exports from a given country to each of these importers in the case of ITN, $i=T$; and the number of countries in which a given country invests weighted by the volume of capital outflows to these countries from a given country in the case of IFN, $i=F)$ :

$$
S_{a, t}^{i}=\sum_{b \neq a \in G_{t}^{i}} s_{a b, t}^{i} w_{a b, t}^{i}, \quad i \in\{T, F\} .
$$

In other words, it is a weighted degree centrality measure, reflecting the importance of a country measured by the volume of its flows in the network. 
Table 1: Correlations among network centrality measures, ITN and IFN.

$\begin{array}{lcccccc} & \text { T.Degree } & \text { T.Strength } & \text { T.Betw. } & \text { F.Degree } & \text { F.Strength } & \text { F.Betw. } \\ \text { T.Degree } & 1.0000 & & & & & \\ \text { T.Strength } & 0.7639 & 1.0000 & & & & \\ \text { T.Betw. } & 0.5719 & 0.6816 & 1.0000 & & & \\ \text { F.Degree } & 0.3945 & 0.4381 & 0.1441 & 1.0000 & & \\ \text { F.Strength } & 0.3632 & 0.5643 & 0.3026 & 0.7457 & 1.0000 & \\ \text { F.Betw. } & 0.3662 & 0.5418 & 0.3424 & 0.8393 & 0.7460 & 1.0000 \\ \end{array}$

Note: This table shows the correlation coefficients between different ITN centralities, based on the data for 1991-2014; the correlation coefficients between different IFN centralities, based on the data for 2001-2014; and the correlation coefficients between different ITN and IFN centralities, based on the data for 2001-2014. "T." and "F." denote network centrality measures for ITN and IFN, respectively.

- Betweenness centrality, $B_{a, t}^{i}, i \in\{T, F\}$, of country a at time $t$, quantifies the number of times a node acts as a bridge along the shortest path between two other nodes. Formally,

$$
B_{a, t}^{i}=\sum_{c \neq a \neq b \in G_{t}^{i}} \frac{\sigma_{c b, t}^{i}(a)}{\sigma_{c b, t}^{i}}, i \in\{T, F\} .
$$

where $\sigma_{c b, t}^{i}$ is total number of shortest paths from node $c$ to node $b$ and $\sigma_{c b, t}^{i}(a)$ is the number of those paths that pass through $a$. This centrality measure evaluates the importance of a country in connecting the other countries. ${ }^{1}$

I normalize all centrality measures by dividing each of them by the maximum value of the corresponding measure across all the considered countries. Thus, by construction, all network centrality measures are in the range between zero and one. Their distributions are skewed to the right, with relatively few countries characterized by high centrality measures relative to the medians across countries. For further analysis, I consider the logarithms of centrality measures, because the corresponding data distributions are much closer to the normal. Table 1 reports the correlation coefficients among the constructed network centrality measures.

To gain some immediate intuition on the possible relationship between the international networks and current account, consider the averages of current account and network centrality measures over the time periods for which the data is available. Given significant differences of current account balances in developed and developing countries (see Chinn and Ito, 2007; Chinn et. al., 2013; and Alfaro et al., 2014), for the purpose of data description, I split the statistics by country's stage of economic development (developing and developed), using the classification of countries by development stage from the United Nations.

\footnotetext{
${ }^{1}$ More definitions and intuition behind these centrality measures can be found, for example, in De Benedictis and Tajoli (2011) and Aller et al. (2015).
} 
Figure 3: Network centrality measures by country income group.
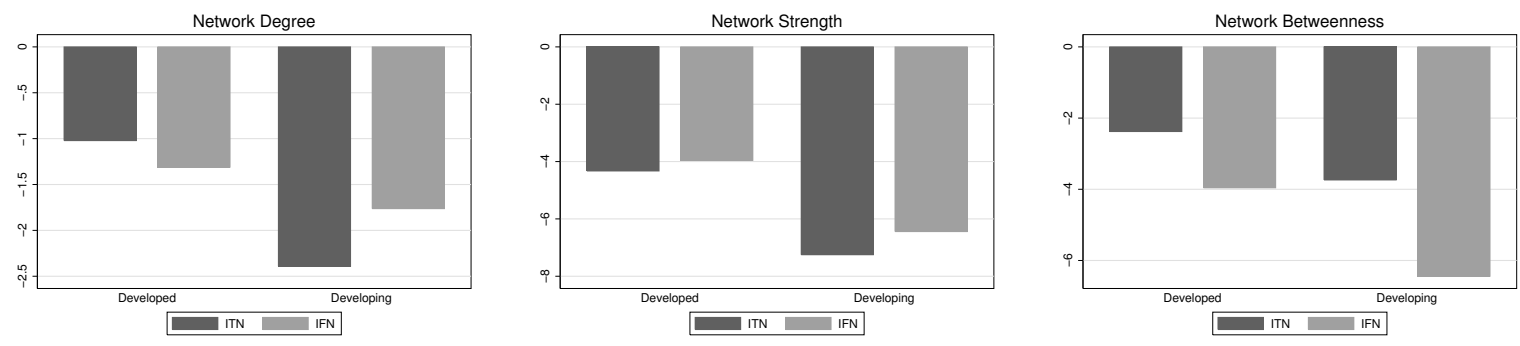

Note: This figure shows the averages of the network centrality measures (in logarithms) for the ITN and IFN, computed over 1991-2014 for developed and developing country groups. Data Source: the Correlates of War Project (Barbieri et al., 2009 and 2016) and the Coordinated Portfolio Investment Survey (CPIS) by the IMF.

Figures 1 and 3 present the current account and the trade and financial networks centrality measures, respectively, by country development stage, all variables averaged over 1991-2014 (2001-2017 for financial network centrality measures). The patterns in the data suggest that there is a tendency for current account and for the importance of the countries in the international networks to increase with economic development (note that network centrality measures are in logarithms so less negative values correspond to higher network centralities). Intuitively, developed countries have more possibilities to trade in goods and services and in the financial assets and are more efficient in accumulating net foreign assets resulting in current account surpluses. Developed economies are characterized by significantly higher centrality measures as compared to developing countries, signalizing the key role of these countries in the international finance and trade relations.

Table 2 reports the correlations between the network centrality measures and current account balances for pooled data, distinguishing between developed and developing countries. The correlation coefficients are positive and significant, regardless of a country's group.

The pattern of correlations presented in Table 2 might be driven by the fact that being a more important member of the international network allows for additional smoothing of internal shocks. It also might be driven by the third factor, such as national income level. In particular, along the development path the economies gain importance in the international relations, so that their current accounts and networks centrality may both increase. In the next section, I perform a more throughout analysis of these correlations and attempt to reveal a causal relationship, if any, between international networks and current account balances. 
Table 2: The correlations among the network centrality measures and current account balances.

\begin{tabular}{|c|c|c|c|c|c|c|}
\hline & (1) & (2) & (3) & (4) & (5) & (6) \\
\hline & & ITN & & \multicolumn{3}{|c|}{ IFN } \\
\hline & Full Sample & Developing & Developed & Full Sample & Developing & Developed \\
\hline Degree & $\begin{array}{c}1.348^{* * *} \\
(0.244)\end{array}$ & $\begin{array}{c}1.041^{* * *} \\
(0.343)\end{array}$ & $\begin{array}{c}2.875^{* * *} \\
(0.422)\end{array}$ & $\begin{array}{c}2.246^{* * *} \\
(0.650)\end{array}$ & $\begin{array}{l}2.403^{*} \\
(1.373)\end{array}$ & $\begin{array}{c}2.530^{* * * *} \\
(0.631)\end{array}$ \\
\hline \multirow[t]{2}{*}{ Strength } & $1.316^{* * *}$ & $1.572^{* * *}$ & $1.189^{* * *}$ & $0.929^{* * *}$ & $1.959^{* * *}$ & $0.849^{* * *}$ \\
\hline & $(0.0949)$ & $(0.132)$ & $(0.138)$ & $(0.180)$ & $(0.448)$ & $(0.175)$ \\
\hline Betweenness & $\begin{array}{c}0.731^{* * *} \\
(0.129)\end{array}$ & $\begin{array}{c}0.587^{* * *} \\
(0.170)\end{array}$ & $\begin{array}{c}0.998^{* * *} \\
(0.165)\end{array}$ & $\begin{array}{c}1.243^{* * *} \\
(0.256)\end{array}$ & $\begin{array}{c}1.162^{* *} \\
(0.584)\end{array}$ & $\begin{array}{c}1.438^{* * *} \\
(0.223)\end{array}$ \\
\hline
\end{tabular}

Note: This table reports the correlation coefficients and their standard errors between the current account balance as a share of GDP and ITN centrality measures, based on annual data for 1991-2014, and between the current account balance as a share of GDP and IFN centrality measures, based on annual data for 2001-2014, in the left and right panel, respectively; ${ }^{* *},{ }^{* *}$, and ${ }^{*}$ indicate significance at $1 \%, 5 \%$, and $10 \%$, respectively.

\section{$5 \quad$ Methodology}

I rely on the econometric specification used by the related studies on current account determinants (see, for example, Chinn and Prasad, 2003; Gruber and Kamin, 2007 and 2009; Chinn and Ito, 2007; Chinn et al., 2013; and Behringer and van Treeck, 2018). In particular, I analyze how the current account balance depends on a set of standard explanatory variables and on the measures of a country's position in the international trade or financial network:

$$
C A_{i, t}=a_{0}+\beta X_{i, t}+\gamma I N_{i, t}+\eta T D_{t}+\epsilon_{i, t},
$$

where $i$ indexes country; $t$ denotes year; $C A_{i, t}$ denotes current account balance as a share of GDP in country $i$ and year $t ; I N_{i, t}$ is the measure (in logarithms) of country $i$ 's position in the international (trade or financial) network at time $t ; X$ is the set of standard explanatory variables taken from Chinn and Ito (2007) and Behringer and van Treeck (2018); T $D_{t}$ is a set of time dummies; and $\epsilon_{i, t}$ is error term.

The set of explanatory variables consists of the following data: the net foreign assets as a share of GDP at the beginning of the considered time period; the real output per capita at the beginning of the considered time period; real output per capita growth rate; fiscal balance (the difference between government revenues and expenditures, as a share of GDP); population growth rate; population dependency ratios (the shares of old and young in total adult population); the standard deviation of the terms of trade (the ratio of the export price index to the import price index); oil rent as a share of GDP; and the private credit share of GDP as a measure of financial development. The data on the government revenues and expenditures 
as shares of GDP is from the World Economic Outlook Database of International Monetary Fund. The net foreign assets share of GDP is taken from Lane and Milesi-Ferretti (2018). All the other variables from set $X$ and the dependent variable, current account balance as a share of GDP, are taken from the World Development Indicators database of the World Bank. Table 3 presents summary statistics for all the variables used in the analysis.

Table 3: Summary Statistics.

\begin{tabular}{|c|c|c|c|c|c|}
\hline VARIABLES & $\begin{array}{c}(1) \\
\text { N obs }\end{array}$ & $\begin{array}{c}(2) \\
\text { Mean }\end{array}$ & $\begin{array}{c}(3) \\
\text { Sd. Dev. }\end{array}$ & $\begin{array}{l}\text { (4) } \\
\text { Min }\end{array}$ & $\begin{array}{l}(5) \\
\operatorname{Max}\end{array}$ \\
\hline $\mathrm{CA} / \mathrm{GDP}$ & 3,604 & -3.169 & 10.06 & -65.03 & 53.69 \\
\hline NFA/GDP & 3,569 & -0.356 & 1.133 & -11.67 & 17.27 \\
\hline Real GDP pc & 3,395 & 8.899 & 1.199 & 6.011 & 11.98 \\
\hline Econ. growth & 3,541 & 2.265 & 4.363 & -37.00 & 33.03 \\
\hline Pop. growth & 3,599 & 1.469 & 1.272 & -3.820 & 9.245 \\
\hline Openness & 3,454 & 85.01 & 48.23 & 0.167 & 441.6 \\
\hline Fiscal bal./GDP & 3,270 & -1.974 & 5.864 & -73.80 & 43.30 \\
\hline Pr. credit/GDP & 3,275 & 45.27 & 41.71 & 0.000823 & 312.0 \\
\hline Polity index & 3,090 & 4.217 & 6.105 & -10 & 10 \\
\hline Terms of Trade & 3,011 & 108.6 & 31.91 & 21.40 & 290.9 \\
\hline Share young & 3,533 & 53.45 & 23.54 & 15.52 & 106.3 \\
\hline Share old & 3,533 & 11.46 & 7.027 & 1.197 & 41.17 \\
\hline Oil rent/GDP & 1,886 & -0.644 & 3.064 & -11.36 & 4.159 \\
\hline Developing & 3,604 & 0.757 & 0.429 & 0 & 1 \\
\hline T.Degree & 3,480 & -2.047 & 1.130 & -5.198 & -0.0111 \\
\hline T.Strenth & 3,480 & -6.516 & 2.734 & -14.80 & 0 \\
\hline T.Betweenness & 3,300 & -3.393 & 2.084 & -10.13 & 0 \\
\hline F.Degree & 858 & -1.520 & 0.751 & -5.398 & -0.323 \\
\hline F.Strength & 858 & -5.108 & 2.693 & -13.00 & 0 \\
\hline F.Betweenness & 849 & -3.352 & 1.947 & -10.55 & 0 \\
\hline T.Avg. dist. partners & 3,480 & 6,045 & 1,253 & 745.4 & 18,082 \\
\hline T.Avg. pop. partners & 3,320 & 114.23 & 93.54 & 0.4468 & $1,296.08$ \\
\hline F.Avg.dist.partners & 2,195 & 8,903 & 4,818 & 136.4 & 19,520 \\
\hline F.Avg.dist.partners' partners & 2,195 & 3,507 & 4,384 & 0 & 10,674 \\
\hline
\end{tabular}

Note: This table reports the summary statistics for all the variables used in the empirical analysis, based on the available data for 1991-2014 for a sample of 175 countries. "T." and "F." denote network centrality measures for ITN and IFN, respectively.

I analyze the impact of international network position on the current account in the medium term, estimating model (4) for a panel of non-overlapping four-year averages of annual observations (similar to Behringer and van Treeck, 2018). ${ }^{2}$ Following Chinn and Ito (2007) and other related studies, I convert all the explanatory variables except for the net foreign assets share of

\footnotetext{
${ }^{2}$ Given the time period for which the network measures are available, five- or more than five-year averages of annual observations result in the panel which is too short for empirical analysis, same as in Behringer and van Treeck, 2018).
} 
GDP, terms of trade, and network centrality measures (because those variables by construction reflect the relative position of a country compared to other countries) into deviations from a GDP-weighted sample mean, prior to taking the four-year averages, so that each country's variables are measured relative to a weighted average of the other countries' values prevailing at the same time. This cross-sectional demeaning accounts for the fact that a given economy's current account is influenced by both domestic and foreign economic conditions.

Following the related studies, I first consider the pooled OLS estimation of model (4). The pooled OLS estimator can be informative if a significant part of the variation in current account comes from the cross-sectional dimension (Chinn and Prasad, 2003; Behringer and van Treeck, 2018). In all estimations, the standard errors are clustered at country level, so that they are robust to heteroscedasticity and serial correlation.

Furthermore, given that a country's position in the international trade network and its current account can be driven by the same unobserved factors, and there is a potential feedback from the state of current account to the country's trade and financial links to other countries, I use the instrumental variable approach to purge off the endogenous component of the network variables. Following the network literature (see Bramoulle et al., 2009) and some of the related studies on the role of international trade networks (see Aller et al., 2015), I use the fundamental characteristics of a country's trading partners, such as the average population in a country's trading partners and the average total geographical distance from a country to its trading partners, as instruments for the international trade network centrality measures. I use the average geographical distance to the countries in which a given country invests and the average geographical distance to the countries in which a given country's neighbors' neighbors invest as instruments for the international financial network centrality measures.

Besides, the fiscal balance is an endogenous explanatory variable, and requires instrumenting, as discussed in Chinn and Ito (2007) and Behringer and van Treeck (2018). Following those authors, I use the unemployment rate, average country's fiscal balance over time, and the polity index, which reflects political regime characteristics (and is available at the Polity IV Project website), as instruments for fiscal balance. The next section presents and discusses the results.

\section{Results}

Table 4 present the results for model (4) estimated by pooled OLS for the international trade network and international financial network centrality measures, in the first and last three 
columns, respectively. I include one network centrality at a time, given that different centrality measures are highly correlated. Each column of Table 4 presents the results where a network centrality stated in the title of the column is included in model (4).

Table 4: Current account and international networks, pooled OLS.

\begin{tabular}{|c|c|c|c|c|c|c|}
\hline VARIABLES & $\begin{array}{c}\text { (1) } \\
\text { Degree }\end{array}$ & $\begin{array}{c}(2) \\
\text { ITN } \\
\text { Strength }\end{array}$ & Betweenness & Degree & $\begin{array}{c}(5) \\
\text { IFN } \\
\text { Strength }\end{array}$ & Betweenness \\
\hline Network Var. & $\begin{array}{c}1.785^{* *} \\
(0.709)\end{array}$ & $\begin{array}{c}1.039^{* * *} \\
(0.245)\end{array}$ & $\begin{array}{c}0.716^{* *} \\
(0.347)\end{array}$ & $\begin{array}{c}0.558 \\
(0.648)\end{array}$ & $\begin{array}{c}0.790^{* * *} \\
(0.257)\end{array}$ & $\begin{array}{c}0.937^{* * *} \\
(0.332)\end{array}$ \\
\hline Developing x Network Var. & $\begin{array}{c}-2.534^{* *} \\
(1.113)\end{array}$ & $\begin{array}{c}-0.0812 \\
(0.391)\end{array}$ & $\begin{array}{l}0.0110 \\
(0.572)\end{array}$ & $\begin{array}{c}3.716 \\
(2.410)\end{array}$ & $\begin{array}{c}0.344 \\
(0.871)\end{array}$ & $\begin{array}{c}0.969 \\
(0.737)\end{array}$ \\
\hline NFA/GDP & $\begin{array}{c}4.623^{* * *} \\
(0.776)\end{array}$ & $\begin{array}{c}4.908^{* * *} \\
(0.485)\end{array}$ & $\begin{array}{c}5.145^{* * *} \\
(0.631)\end{array}$ & $\begin{array}{c}8.563^{* * *} \\
(0.982)\end{array}$ & $\begin{array}{c}8.633^{* * *} \\
(1.094)\end{array}$ & $\begin{array}{c}7.885^{* * *} \\
(0.943)\end{array}$ \\
\hline Real GDP pc & $\begin{array}{l}1.646^{*} \\
(0.969)\end{array}$ & $\begin{array}{c}0.480 \\
(0.902)\end{array}$ & $\begin{array}{l}1.467^{*} \\
(0.858)\end{array}$ & $\begin{array}{l}-1.084 \\
(1.089)\end{array}$ & $\begin{array}{l}-2.834^{*} \\
(1.667)\end{array}$ & $\begin{array}{l}-1.715^{*} \\
(0.887)\end{array}$ \\
\hline Pop. growth & $\begin{array}{l}-0.0944 \\
(0.511)\end{array}$ & $\begin{array}{l}-0.168 \\
(0.470)\end{array}$ & $\begin{array}{l}-0.174 \\
(0.495)\end{array}$ & $\begin{array}{l}-0.602 \\
(0.632)\end{array}$ & $\begin{array}{l}-0.647 \\
(0.630)\end{array}$ & $\begin{array}{l}-0.373 \\
(0.548)\end{array}$ \\
\hline Oil rent/GDP & $\begin{array}{c}0.393^{* * *} \\
(0.125)\end{array}$ & $\begin{array}{r}0.277^{* *} \\
(0.138)\end{array}$ & $\begin{array}{c}0.412^{* * *} \\
(0.123)\end{array}$ & $\begin{array}{l}0.0906 \\
(0.189)\end{array}$ & $\begin{array}{l}0.0996 \\
(0.202)\end{array}$ & $\begin{array}{l}0.0158 \\
(0.175)\end{array}$ \\
\hline Terms of Trade & $\begin{array}{l}0.113^{* *} \\
(0.0536)\end{array}$ & $\begin{array}{l}0.114^{* *} \\
(0.0512)\end{array}$ & $\begin{array}{l}0.124^{* *} \\
(0.0534)\end{array}$ & $\begin{array}{c}0.0412 \\
(0.0649)\end{array}$ & $\begin{array}{l}0.00714 \\
(0.0771)\end{array}$ & $\begin{array}{l}0.0910^{*} \\
(0.0525)\end{array}$ \\
\hline Share young & $\begin{array}{c}0.0119 \\
(0.0442)\end{array}$ & $\begin{array}{l}0.00978 \\
(0.0444)\end{array}$ & $\begin{array}{c}0.0265 \\
(0.0482)\end{array}$ & $\begin{array}{c}0.271^{* * *} \\
(0.0997)\end{array}$ & $\begin{array}{c}0.163^{*} \\
(0.0833)\end{array}$ & $\begin{array}{l}0.233^{* * *} \\
(0.0792)\end{array}$ \\
\hline Share old & $\begin{array}{l}0.0375 \\
(0.152)\end{array}$ & $\begin{array}{l}0.0360 \\
(0.133)\end{array}$ & $\begin{array}{l}0.0313 \\
(0.159)\end{array}$ & $\begin{array}{c}0.156 \\
(0.132)\end{array}$ & $\begin{array}{l}0.0716 \\
(0.122)\end{array}$ & $\begin{array}{c}0.155 \\
(0.120)\end{array}$ \\
\hline Econ. growth & $\begin{array}{l}-0.0996 \\
(0.174)\end{array}$ & $\begin{array}{l}-0.197 \\
(0.179)\end{array}$ & $\begin{array}{l}-0.108 \\
(0.191)\end{array}$ & $\begin{array}{l}-0.613^{*} \\
(0.309)\end{array}$ & $\begin{array}{c}-0.636^{* *} \\
(0.307)\end{array}$ & $\begin{array}{c}-0.558^{* *} \\
(0.246)\end{array}$ \\
\hline Fiscal Bal./GDP & $\begin{array}{l}0.00239 \\
(0.0104)\end{array}$ & $\begin{array}{c}-0.0103 \\
(0.00935)\end{array}$ & $\begin{array}{r}-0.00220 \\
(0.0103)\end{array}$ & $\begin{array}{l}-0.00944 \\
(0.0128)\end{array}$ & $\begin{array}{l}-0.0148 \\
(0.0133)\end{array}$ & $\begin{array}{l}-0.0189 \\
(0.0126)\end{array}$ \\
\hline Gov. deficit/GDP & $\begin{array}{c}0.462^{* * *} \\
(0.0812)\end{array}$ & $\begin{array}{c}0.484^{* * *} \\
(0.0678)\end{array}$ & $\begin{array}{l}0.456^{* * *} \\
(0.0740)\end{array}$ & $\begin{array}{c}0.445^{* * *} \\
(0.0965)\end{array}$ & $\begin{array}{c}0.478^{* * *} \\
(0.0919)\end{array}$ & $\begin{array}{l}0.496^{* * *} \\
(0.0800)\end{array}$ \\
\hline Openness & $\begin{array}{l}0.00968 \\
(0.0128)\end{array}$ & $\begin{array}{c}0.0284^{* * * *} \\
(0.0106)\end{array}$ & $\begin{array}{l}0.0254^{*} \\
(0.0140)\end{array}$ & $\begin{array}{c}0.0480^{* * *} \\
(0.0122)\end{array}$ & $\begin{array}{c}0.0590^{* * *} \\
(0.0136)\end{array}$ & $\begin{array}{c}0.0562^{* * *} \\
(0.0103)\end{array}$ \\
\hline Constant & $\begin{array}{l}-5.306 \\
(7.300)\end{array}$ & $\begin{array}{l}-1.426 \\
(6.587)\end{array}$ & $\begin{array}{l}-3.894 \\
(7.317)\end{array}$ & $\begin{array}{l}27.36^{*} \\
(15.34)\end{array}$ & $\begin{array}{c}17.36 \\
(13.69)\end{array}$ & $\begin{array}{c}26.10^{* *} \\
(11.55)\end{array}$ \\
\hline $\begin{array}{l}\text { Observations } \\
\text { R-squared }\end{array}$ & $\begin{array}{c}376 \\
0.650\end{array}$ & $\begin{array}{c}376 \\
0.669\end{array}$ & $\begin{array}{c}371 \\
0.656\end{array}$ & $\begin{array}{c}178 \\
0.760\end{array}$ & $\begin{array}{c}178 \\
0.760\end{array}$ & $\begin{array}{c}177 \\
0.800\end{array}$ \\
\hline
\end{tabular}

Robust standard errors in parentheses $* * * \mathrm{p}<0.01,{ }^{* *} \mathrm{p}<0.05, * \mathrm{p}<0.1$

Note: This table reports the coefficients and their standard errors for model (4) estimated by Pooled OLS over four-year non-overlapping periods for 1991-2014 where the network variable (Network Var.) included is stated in the top of Columns (1)-(3) for ITN and Columns (4)-(6) for IFN, respectively. Time dummies are included in all estimations; standard errors are clustered by country; ${ }^{* *}, * *$, and $*$ indicate significance at $1 \%, 5 \%$, and $10 \%$, respectively.

First, consider the results for ITN, presented in Columns (1)-(3) of Table 4. All network 
centrality measures have positive and significant coefficients. For the degree centrality, the results suggest that a one percent increase in the network degree of a country (that is, adding a one percent more export links to other countries) is associated with 1.785 percent increase in the share of current account balance to GDP, ${ }^{3}$ on average, for developed countries. At the same time, a one percent increase in a country's network degree is associated with a decline in the current account share of GDP for developing countries. A one percent increase in a country's strength or betweenness is associated with 1-0.7 percent increase in current account share of GDP in both developed and developing countries. Overall, the estimation results suggest that a more central position in the international trade network has positive impact on current account in developed countries but might lead to a decline in the current account in developing countries.

Next, consider the results for IFN, presented in Columns (3)-(6) of Table 4. A country's strength and betweenness network centrality measures have positive and significant coefficients, indicating that a one percent increase in these centralities is associated with around one percent increase in the current account balance as a share of GDP, both in developed and developing countries (given that the interactions of these network centralities with developing countries dummy are insignificant). The impact of IFN degree centrality on current account is insignificant.

The coefficients on the control variables are in line with those obtained by the related studies. In particular, higher real output per capita, openness to trade, and government balance are associated with higher current balance, while population growth is associated with a deterioration in the current account balance.

Thus, the pooled OLS estimation results suggest that a better position in the international trade network is likely to improve current account. Before discussing any intuition behind these results, I check whether they are robust to different estimation methods.

\footnotetext{
${ }^{3}$ Note that current account balance as a share of GDP is measured as a fraction in the data.
} 
Table 5: Current account and international networks, pooled OLS- $I V^{1}$

\begin{tabular}{|c|c|c|c|c|c|c|}
\hline VARIABLES & $\begin{array}{c}(1) \\
\text { Degree }\end{array}$ & $\begin{array}{c}(2) \\
\text { ITN } \\
\text { Strength }\end{array}$ & Betweenness & $\begin{array}{c}(4) \\
\text { Degree }\end{array}$ & $\begin{array}{c}(5) \\
\text { IFN } \\
\text { Strength }\end{array}$ & Betweenness \\
\hline Network Var. & $\begin{array}{l}1.269 \\
(0.973)\end{array}$ & $\begin{array}{c}1.076^{* *} \\
(0.477)\end{array}$ & $\begin{array}{c}1.452^{* * *} \\
(0.540)\end{array}$ & $\begin{array}{c}0.123 \\
(1.108)\end{array}$ & $\begin{array}{l}1.323^{*} \\
(0.720)\end{array}$ & $\begin{array}{c}1.400^{* *} \\
(0.587)\end{array}$ \\
\hline Developing x Network Var. & $\begin{array}{l}-1.480 \\
(1.096)\end{array}$ & $\begin{array}{l}-0.107 \\
(0.332)\end{array}$ & $\begin{array}{l}-0.370 \\
(0.517)\end{array}$ & $\begin{array}{c}1.368 \\
(1.569)\end{array}$ & $\begin{array}{c}0.274 \\
(0.374)\end{array}$ & $\begin{array}{c}0.578 \\
(0.484)\end{array}$ \\
\hline NFA/GDP & $\begin{array}{c}6.287^{* * *} \\
(0.890)\end{array}$ & $\begin{array}{c}5.746^{* * *} \\
(0.852)\end{array}$ & $\begin{array}{c}5.975^{* * *} \\
(0.844)\end{array}$ & $\begin{array}{c}9.520^{* * *} \\
(1.178)\end{array}$ & $\begin{array}{c}9.172^{* * *} \\
(1.185)\end{array}$ & $\begin{array}{c}8.226^{* * * *} \\
(0.980)\end{array}$ \\
\hline Real GDP pc & $\begin{array}{c}2.029^{* *} \\
(0.874)\end{array}$ & $\begin{array}{c}1.047 \\
(1.033)\end{array}$ & $\begin{array}{c}1.830^{* *} \\
(0.764)\end{array}$ & $\begin{array}{c}0.810 \\
(0.934)\end{array}$ & $\begin{array}{l}-2.869 \\
(2.358)\end{array}$ & $\begin{array}{l}-0.887 \\
(0.937)\end{array}$ \\
\hline Pop. growth & $\begin{array}{l}-0.683 \\
(0.538)\end{array}$ & $\begin{array}{l}-0.691 \\
(0.518)\end{array}$ & $\begin{array}{l}-0.713 \\
(0.549)\end{array}$ & $\begin{array}{l}-1.074^{*} \\
(0.571)\end{array}$ & $\begin{array}{l}-0.833 \\
(0.541)\end{array}$ & $\begin{array}{l}-0.682 \\
(0.487)\end{array}$ \\
\hline Oil rent/GDP & $\begin{array}{c}0.171^{* *} \\
(0.0822)\end{array}$ & $\begin{array}{l}0.0727 \\
(0.109)\end{array}$ & $\begin{array}{c}0.133 \\
(0.0909)\end{array}$ & $\begin{array}{c}-0.0526 \\
(0.136)\end{array}$ & $\begin{array}{r}-0.0870 \\
(0.158)\end{array}$ & $\begin{array}{l}-0.126 \\
(0.132)\end{array}$ \\
\hline Terms of Trade & $\begin{array}{c}0.179^{* * *} \\
(0.0472)\end{array}$ & $\begin{array}{c}0.177^{* * *} \\
(0.0477)\end{array}$ & $\begin{array}{c}0.197^{* * *} \\
(0.0461)\end{array}$ & $\begin{array}{c}0.0780 \\
(0.0667)\end{array}$ & $\begin{array}{c}0.0689 \\
(0.0682)\end{array}$ & $\begin{array}{c}0.146^{* * *} \\
(0.0425)\end{array}$ \\
\hline Pop. dependency & $\begin{array}{c}-0.0943 \\
(0.110)\end{array}$ & $\begin{array}{l}-0.160 \\
(0.100)\end{array}$ & $\begin{array}{c}-0.145 \\
(0.0966)\end{array}$ & $\begin{array}{c}-0.0111 \\
(0.104)\end{array}$ & $\begin{array}{c}-0.0668 \\
(0.131)\end{array}$ & $\begin{array}{l}0.00693 \\
(0.0896)\end{array}$ \\
\hline Share young & $\begin{array}{c}0.142 \\
(0.115)\end{array}$ & $\begin{array}{c}0.204^{* *} \\
(0.103)\end{array}$ & $\begin{array}{l}0.200^{* *} \\
(0.0977)\end{array}$ & $\begin{array}{c}0.261 \\
(0.162)\end{array}$ & $\begin{array}{c}0.207 \\
(0.143)\end{array}$ & $\begin{array}{c}0.209 \\
(0.127)\end{array}$ \\
\hline Econ. growth & $\begin{array}{c}0.0112 \\
(0.0964)\end{array}$ & $\begin{array}{l}-0.0372 \\
(0.0957)\end{array}$ & $\begin{array}{c}-0.0188 \\
(0.101)\end{array}$ & $\begin{array}{l}-0.246 \\
(0.161)\end{array}$ & $\begin{array}{c}-0.259^{*} \\
(0.156)\end{array}$ & $\begin{array}{c}-0.267^{*} \\
(0.137)\end{array}$ \\
\hline Pr. credit/GDP & $\begin{array}{c}0.0108 \\
(0.00871)\end{array}$ & $\begin{array}{r}-0.00119 \\
(0.0104)\end{array}$ & $\begin{array}{l}0.00420 \\
(0.0111)\end{array}$ & $\begin{array}{c}-0.00497 \\
(0.0137)\end{array}$ & $\begin{array}{l}-0.0235 \\
(0.0160)\end{array}$ & $\begin{array}{l}-0.0243 \\
(0.0153)\end{array}$ \\
\hline Fiscal bal./GDP & $\begin{array}{c}0.355^{* * *} \\
(0.0693)\end{array}$ & $\begin{array}{c}0.403^{* * *} \\
(0.0720)\end{array}$ & $\begin{array}{c}0.389^{* * *} \\
(0.0696)\end{array}$ & $\begin{array}{c}0.317^{* * *} \\
(0.0752)\end{array}$ & $\begin{array}{c}0.379^{* * *} \\
(0.0989)\end{array}$ & $\begin{array}{c}0.393^{* * *} \\
(0.0782)\end{array}$ \\
\hline Openness & $\begin{array}{c}0.0155 \\
(0.0106)\end{array}$ & $\begin{array}{c}0.0253^{* *} \\
(0.0102)\end{array}$ & $\begin{array}{c}0.0287^{* *} \\
(0.0131)\end{array}$ & $\begin{array}{c}0.0406^{* * *} \\
(0.0134)\end{array}$ & $\begin{array}{c}0.0558^{* * *} \\
(0.0151)\end{array}$ & $\begin{array}{c}0.0501^{* * *} \\
(0.0104)\end{array}$ \\
\hline Constant & $\begin{array}{c}0.288 \\
(6.847)\end{array}$ & $\begin{array}{c}7.997 \\
(8.288)\end{array}$ & $\begin{array}{c}5.208 \\
(6.454)\end{array}$ & $\begin{array}{l}29.95^{*} \\
(17.95)\end{array}$ & $\begin{array}{c}27.33^{* *} \\
(13.36)\end{array}$ & $\begin{array}{c}33.74^{* * *} \\
(12.70)\end{array}$ \\
\hline $\begin{array}{l}\text { Observations } \\
\text { R-squared }\end{array}$ & $\begin{array}{c}352 \\
0.577\end{array}$ & $\begin{array}{c}352 \\
0.582\end{array}$ & $\begin{array}{c}348 \\
0.562\end{array}$ & $\begin{array}{c}175 \\
0.739\end{array}$ & $\begin{array}{c}175 \\
0.717\end{array}$ & $\begin{array}{c}174 \\
0.773\end{array}$ \\
\hline $\begin{array}{l}\text { Cragg-Donald Wald F } \\
\text { Hansen test p-val. } \\
\text { Endog. test p-val. }\end{array}$ & $\begin{array}{l}19.261 \\
0.1352 \\
0.8283\end{array}$ & $\begin{array}{l}12.141 \\
0.0785 \\
0.9318\end{array}$ & $\begin{array}{l}12.608 \\
0.1883 \\
0.2568\end{array}$ & $\begin{array}{c}9.198 \\
0.0839 \\
0.3293\end{array}$ & $\begin{array}{c}3.251 \\
0.1616 \\
0.8244\end{array}$ & $\begin{array}{c}6.140 \\
0.1198 \\
0.6545\end{array}$ \\
\hline
\end{tabular}

Note: This table reports the coefficients and their standard errors for model (4) estimated by Pooled OLS-IV over four-year non-overlapping periods for 1991-2014 where the network variable (Network Var.) included is stated in the top of Columns (1)-(3) for ITN and Columns (4)-(6) for IFN, respectively. Fiscal balance is instrumented by unemployment, polity index, and average country's fiscal balance over time. Network variables are instrumented by average geographical distance to trading partners and average population of trading partners (for ITN) or average geographical distance to partners (recipients of a country's investment flows) and average geographical distance to partners' partners (for IFN). Time dummies are included in all estimations; ${ }^{* *},{ }^{* *}$, and $*$ indicate significance at $1 \%, 5 \%$, and $10 \%$, respectively.

First, I re-estimate model (4) by pooled OLS instrumenting (IV) the network variables, as 
follows. For ITN, the network variables are instrumented by the average geographical distance to trading partners and average population of trading partners. For IFN, the network variables are instrumented by the average geographical distance to partners (recipients of a country's investment flows) and the average geographical distance to partners' partners. Table 5 presents the results. The results from pooled OLS-IV estimates are very similar to those obtained without instrumenting. The impact of a country's position in the international networks as measured by strength and betweenness on current account is positive for both developed and developing countries. The degree network centrality does not have any impact on current account, according to pooled OLS-IV estimates.

The diagnostic tests performed after the pooled OLS-IV estimation for each network variable and reported in the last three rows of Table 5 indicate that the instruments are valid; moreover, the hypothesis that the network centrality is exogenous cannot be rejected while the exogeneity of fiscal balance is strongly rejected. Thus, the estimates where network variables are not instrumented are more efficient, while the fiscal balance should be instrumented to obtain consistent estimates.

Therefore, next I re-estimate model (4) by pooled OLS where only fiscal balance is instrumented by unemployment rate, average country's fiscal balance over time, and polity index. The results are reported in Table 6 . The estimated coefficients are very similar to their OLS counterparts.

Overall, the results indicate that a better position in the international financial network improves the current account balance in developed and developing countries. These results are consistent with the hypotheses stated in Section 3 of this paper. More connected countries can better diversify their trade and financial risks. Besides, the positive impact of networks (due to, for example, more possibilities to diversify risks) overweights the negative impact (due to spillovers from the trading partners) for the international financial network and for the international trade network in developed countries, but not for the international trade network in developing countries (given that the degree centrality has a negative and significant coefficient for developing countries. This could be because developing countries are less able to efficiently react on the changes in domestic and foreign economic conditions (due to, for example, underdeveloped legislative base or inefficient domestic markets). 
Table 6: Current account and international networks, pooled OLS- $I V^{2}$.

\begin{tabular}{|c|c|c|c|c|c|c|}
\hline \multirow[b]{2}{*}{ VARIABLES } & \multicolumn{3}{|c|}{ ITN } & \multicolumn{3}{|c|}{ IFN } \\
\hline & Degree & Strength & Betweenness & Degree & Strength & Betweenness \\
\hline \multirow[t]{2}{*}{ Network Var. } & $1.828^{* * *}$ & $1.020^{* * *}$ & $0.746^{* *}$ & 0.357 & $0.547^{* *}$ & $0.847^{* * *}$ \\
\hline & $(0.663)$ & $(0.264)$ & $(0.319)$ & $(0.649)$ & $(0.220)$ & $(0.280)$ \\
\hline \multirow{2}{*}{ Developing x Network Var. } & $-3.003^{* * *}$ & -0.304 & -0.341 & 3.128 & 0.227 & 1.026 \\
\hline & $(1.008)$ & $(0.398)$ & $(0.585)$ & $(2.713)$ & $(1.035)$ & $(0.832)$ \\
\hline \multirow[t]{2}{*}{ NFA/GDP } & $5.572^{* * *}$ & $5.165^{* * *}$ & $5.533^{* * *}$ & $8.731^{* * *}$ & $8.771^{* * *}$ & $7.953^{* * *}$ \\
\hline & $(0.906)$ & $(0.865)$ & $(0.856)$ & (1.193) & (1.431) & $(1.142)$ \\
\hline \multirow[t]{2}{*}{ Real GDP pc } & $2.341^{* * *}$ & 1.343 & $2.061^{* * *}$ & 0.511 & -0.723 & -0.434 \\
\hline & $(0.783)$ & $(0.858)$ & $(0.781)$ & $(0.711)$ & $(1.369)$ & $(0.709)$ \\
\hline \multirow[t]{2}{*}{ Pop. growth } & $-1.176^{* *}$ & $-1.108^{* *}$ & $-1.016^{* *}$ & $-1.073^{*}$ & $-1.089 * *$ & -0.796 \\
\hline & $(0.499)$ & $(0.529)$ & $(0.516)$ & $(0.559)$ & $(0.430)$ & $(0.522)$ \\
\hline \multirow[t]{2}{*}{ Oil rent/GDP } & 0.0327 & -0.0459 & 0.0349 & -0.0745 & -0.106 & -0.153 \\
\hline & $(0.107)$ & $(0.111)$ & $(0.106)$ & $(0.130)$ & $(0.121)$ & $(0.120)$ \\
\hline \multirow{2}{*}{ Terms of Trade } & $0.164^{* * *}$ & $0.159^{* * *}$ & $0.165^{* * *}$ & 0.0773 & 0.0530 & $0.130 * * *$ \\
\hline & $(0.0503)$ & $(0.0486)$ & $(0.0492)$ & $(0.0581)$ & $(0.0717)$ & $(0.0408)$ \\
\hline \multirow{2}{*}{ Pop. dependency } & -0.164 & $-0.212^{* *}$ & $-0.188^{*}$ & 0.000229 & -0.0749 & -0.00583 \\
\hline & $(0.107)$ & $(0.106)$ & $(0.111)$ & $(0.0955)$ & $(0.0871)$ & $(0.0917)$ \\
\hline \multirow[t]{2}{*}{ Share young } & $0.224^{* *}$ & $0.264^{* *}$ & $0.249^{* *}$ & $0.285^{* *}$ & $0.272^{* *}$ & $0.267^{* *}$ \\
\hline & $(0.114)$ & $(0.108)$ & $(0.111)$ & $(0.140)$ & $(0.119)$ & $(0.120)$ \\
\hline \multirow[t]{2}{*}{ Econ. growth } & -0.0711 & -0.0737 & -0.0396 & $-0.280^{* *}$ & $-0.278^{* *}$ & $-0.286^{* *}$ \\
\hline & $(0.100)$ & $(0.0950)$ & $(0.0990)$ & $(0.141)$ & $(0.135)$ & $(0.127)$ \\
\hline \multirow[t]{2}{*}{ Pr. credit/GDP } & 0.00700 & -0.00111 & 0.00730 & -0.00764 & -0.00956 & -0.0172 \\
\hline & $(0.00883)$ & $(0.00897)$ & $(0.00980)$ & $(0.0125)$ & $(0.0126)$ & $(0.0117)$ \\
\hline \multirow[t]{2}{*}{ Fiscal Bal./GDP } & $0.553^{* * *}$ & $0.600^{* * *}$ & $0.544^{* * *}$ & $0.410^{* * *}$ & $0.443^{* * *}$ & $0.479^{* * *}$ \\
\hline & $(0.130)$ & $(0.118)$ & $(0.120)$ & $(0.0931)$ & $(0.0861)$ & $(0.0922)$ \\
\hline \multirow{2}{*}{ Openness } & 0.00511 & $0.0200^{*}$ & 0.0171 & $0.0382^{* * *}$ & $0.0451^{* * *}$ & $0.0459^{* * *}$ \\
\hline & $(0.0117)$ & $(0.0104)$ & $(0.0125)$ & $(0.0125)$ & $(0.0128)$ & $(0.0103)$ \\
\hline \multirow[t]{2}{*}{ Constant } & 4.138 & 8.576 & 5.070 & $35.71^{* *}$ & $27.47^{*}$ & $37.15^{* * *}$ \\
\hline & $(7.087)$ & $(7.123)$ & $(7.133)$ & $(17.19)$ & $(15.49)$ & $(12.36)$ \\
\hline Observations & 360 & 360 & 355 & 175 & 175 & 174 \\
\hline R-squared & 0.569 & 0.570 & 0.567 & 0.741 & 0.734 & 0.777 \\
\hline Cragg-Donald Wald F & 67.577 & 64.724 & 68.825 & 66.525 & 63.024 & 61.516 \\
\hline Hansen test p-val. & 0.1328 & 0.0981 & 0.1223 & 0.6584 & 0.6785 & 0.6722 \\
\hline Endog. test p-val. & 0.1019 & 0.0339 & 0.0823 & 0.0537 & 0.0336 & 0.0163 \\
\hline
\end{tabular}

Note: This table reports the coefficients and their standard errors for model (4) estimated by Pooled OLS-IV over four-year non-overlapping periods for 1991-2014 where the network variable (Network Var.) included is stated in the top of Columns (1)-(3) for ITN and Columns (4)-(6) for IFN, respectively. The fiscal balance is instrumented, by unemployment, average country's fiscal balance over time, and polity index. Time dummies are included in all estimations; ${ }^{* *},{ }^{* *}$, and $*$ indicate significance at $1 \%, 5 \%$, and $10 \%$, respectively.

Furthermore, I re-estimate model (4) controlling for country-specific fixed effect; controlling for country-specific fixed effect where the network variables and fiscal balance are instrumented; and controlling for country-specific fixed effect where only fiscal balance is instrumented. The 
results indicate that the impact of a country's international network position on current account is not significant if the analysis is restricted to within-country variation in current account balances. One potential reason is that the network structure does not change significantly over time. As discussed in Chinn and Prasad (2003) and Behringer and van Treeck (2018), including country fixed effects removes much of the cross-country variation which is problematic in the context of current account estimations since much of variation in the data stems from the cross-sectional dimension.

\subsection{Impact of networks over time}

The analysis above concentrates on the medium-term determinants of current account. Reestimation of model (4) for annual data does not deliver any robust pattern of relationship between ITN or IFN and current account. One reason is that the network centrality measures are persistent and do not change significantly over time.

Even though a particular country's position in the network usually does not change significantly in the short to medium term, the impact of this position on the current account may change over time. In particular, as financial and trade integration become more widespread, the impact of the main variables of interest on current account may change.

The estimation results for the baseline pooled OLS-IV specification augmented by the interactions of time dummies and network centrality measures, with instrumented fiscal balance, are reported in Table 7 for the international trade and financial networks, in Columns (1)-(3) and Columns (4)-(6), respectively. The results suggest that the international financial networks have become more important for the current account balances over time. In particular, compared to the beginning of 2000s, the impact of an increase in the number of international links on a country's current account has more than doubled. At the same time, the impact of international trade network remained constant over the considered time period for developed countries and decreased over time for developing countries. Intuitively, the international trade network is more established than the international financial network. The raising importance of international financial network centralities are consistent with the raising share of finance in the world economy, caused by financial development and financial liberalization. 
Table 7: Impact of international networks on current account over time, Pooled OLS-IV

\begin{tabular}{|c|c|c|c|c|c|c|}
\hline \multirow[b]{2}{*}{ VARIABLES } & \multicolumn{3}{|c|}{ ITN } & \multicolumn{3}{|c|}{ IFN } \\
\hline & Degree & Strength & Betweenness & Degree & Strength & Betweenness \\
\hline Network & $\begin{array}{c}1.225 \\
(1.155)\end{array}$ & $\begin{array}{c}1.621^{* * *} \\
(0.467)\end{array}$ & $\begin{array}{l}1.720^{* *} \\
(0.765)\end{array}$ & $\begin{array}{c}-1.489^{* *} \\
(0.622)\end{array}$ & $\begin{array}{l}0.0374 \\
(0.316)\end{array}$ & $\begin{array}{l}0.525 \\
(0.465)\end{array}$ \\
\hline Period(2000-2003) x Network & $\begin{array}{l}-0.898 \\
(1.190)\end{array}$ & $\begin{array}{c}-1.044^{* *} \\
(0.437)\end{array}$ & $\begin{array}{l}-1.019 \\
(0.786)\end{array}$ & & & \\
\hline Period(2004-2007) x Network & $\begin{array}{c}0.593 \\
(1.316)\end{array}$ & $\begin{array}{l}-0.313 \\
(0.511)\end{array}$ & $\begin{array}{l}-0.771 \\
(0.829)\end{array}$ & $\begin{array}{l}2.357^{* *} \\
(1.017)\end{array}$ & $\begin{array}{c}0.721^{* * *} \\
(0.280)\end{array}$ & $\begin{array}{c}0.978^{* *} \\
(0.401)\end{array}$ \\
\hline Period(2008-2011) x Network & $\begin{array}{c}0.321 \\
(1.234)\end{array}$ & $\begin{array}{l}-0.412 \\
(0.427)\end{array}$ & $\begin{array}{l}-0.559 \\
(0.828)\end{array}$ & $\begin{array}{c}3.294^{* * *} \\
(0.838)\end{array}$ & $\begin{array}{c}1.040^{* * *} \\
(0.303)\end{array}$ & $\begin{array}{c}0.690 \\
(0.520)\end{array}$ \\
\hline Period(2012-2014) x Network & $\begin{array}{l}0.375 \\
(1.236)\end{array}$ & $\begin{array}{l}-0.610 \\
(0.411)\end{array}$ & $\begin{array}{r}-1.422^{*} \\
(0.816)\end{array}$ & $\begin{array}{c}3.483^{* * *} \\
(1.190)\end{array}$ & $\begin{array}{l}0.753^{*} \\
(0.424)\end{array}$ & $\begin{array}{l}0.343 \\
(0.601)\end{array}$ \\
\hline Period(1996-1999) x Dev x Network & $\begin{array}{c}-3.131^{* *} \\
(1.376)\end{array}$ & $\begin{array}{c}-1.430^{* * * *} \\
(0.533)\end{array}$ & $\begin{array}{l}-1.006 \\
(0.802)\end{array}$ & & & \\
\hline Period(2000-2003) x Dev x Network & $\begin{array}{c}-3.576^{* * * *} \\
(0.918)\end{array}$ & $\begin{array}{c}-1.605^{* * *} \\
(0.384)\end{array}$ & $\begin{array}{c}-1.945^{* * *} \\
(0.719)\end{array}$ & & & \\
\hline Period(2004-2007) x Dev x Network & $\begin{array}{c}-3.716^{* * * *} \\
(1.036)\end{array}$ & $\begin{array}{c}-1.414^{* * * *} \\
(0.451)\end{array}$ & $\begin{array}{c}-2.519^{* * *} \\
(0.676)\end{array}$ & $\begin{array}{l}2.257^{*} \\
(1.156)\end{array}$ & $\begin{array}{l}0.195 \\
(0.367)\end{array}$ & $\begin{array}{c}0.665 \\
(0.546)\end{array}$ \\
\hline Period(2008-2011) x Dev x Network & $\begin{array}{c}-1.529^{* * *} \\
(0.569)\end{array}$ & $\begin{array}{c}-0.608^{* *} \\
(0.270)\end{array}$ & $\begin{array}{l}-0.837^{*} \\
(0.435)\end{array}$ & $\begin{array}{c}4.171^{* * *} \\
(1.602)\end{array}$ & $\begin{array}{c}0.800 \\
(0.530)\end{array}$ & $\begin{array}{l}1.108 \\
(0.724)\end{array}$ \\
\hline Period(2012-2014) x Dev x Network & & & & $\begin{array}{c}5.482^{* * *} \\
(1.801)\end{array}$ & $\begin{array}{l}0.835 \\
(0.549)\end{array}$ & $\begin{array}{c}0.996 \\
(0.726)\end{array}$ \\
\hline Period(1996-1999) & $\begin{array}{c}-7.898^{* * * *} \\
(2.260)\end{array}$ & $\begin{array}{l}-3.675 \\
(4.130)\end{array}$ & $\begin{array}{l}-3.855^{*} \\
(2.218)\end{array}$ & & & \\
\hline $\operatorname{Period}(2000-2003)$ & $\begin{array}{c}-5.385^{* *} \\
(2.736)\end{array}$ & $\begin{array}{l}-0.788 \\
(4.661)\end{array}$ & $\begin{array}{l}-2.923 \\
(1.968)\end{array}$ & & & \\
\hline Period(2004-2007) & $\begin{array}{l}-1.496 \\
(2.613)\end{array}$ & $\begin{array}{c}4.797 \\
(4.878)\end{array}$ & $\begin{array}{c}0.276 \\
(2.327)\end{array}$ & $\begin{array}{c}5.338^{* * *} \\
(1.886)\end{array}$ & $\begin{array}{c}5.491^{* * *} \\
(1.767)\end{array}$ & $\begin{array}{c}4.797^{* * *} \\
(1.800)\end{array}$ \\
\hline Period(2008-2011) & $\begin{array}{l}-0.152 \\
(3.560)\end{array}$ & $\begin{array}{l}6.299 \\
(5.481)\end{array}$ & $\begin{array}{l}2.101 \\
(3.194)\end{array}$ & $\begin{array}{c}2.086 \\
(2.417)\end{array}$ & $\begin{array}{l}2.111 \\
(2.499)\end{array}$ & $\begin{array}{l}1.122 \\
(2.528)\end{array}$ \\
\hline Period(2012-2014) & $\begin{array}{l}-0.536 \\
(3.484)\end{array}$ & $\begin{array}{l}5.806 \\
(5.545)\end{array}$ & $\begin{array}{l}1.311 \\
(3.224)\end{array}$ & $\begin{array}{l}2.130 \\
(2.370)\end{array}$ & $\begin{array}{l}-0.299 \\
(2.531)\end{array}$ & $\begin{array}{l}-1.749 \\
(2.379)\end{array}$ \\
\hline NFA/GDP & $\begin{array}{c}6.444^{* * *} \\
(0.835)\end{array}$ & $\begin{array}{c}6.102^{* * *} \\
(0.751)\end{array}$ & $\begin{array}{c}6.535^{* * *} \\
(0.831)\end{array}$ & $\begin{array}{c}8.727^{* * *} \\
(0.888)\end{array}$ & $\begin{array}{c}8.503^{* * *} \\
(0.995)\end{array}$ & $\begin{array}{c}8.019^{* * *} \\
(0.839)\end{array}$ \\
\hline Real GDP pc & $\begin{array}{l}1.987^{* *} \\
(0.839)\end{array}$ & $\begin{array}{c}0.977 \\
(0.859)\end{array}$ & $\begin{array}{l}1.709^{* *} \\
(0.826)\end{array}$ & $\begin{array}{l}-0.791 \\
(0.943)\end{array}$ & $\begin{array}{l}-1.763 \\
(1.280)\end{array}$ & $\begin{array}{l}-1.482^{*} \\
(0.832)\end{array}$ \\
\hline Pop. growth & $\begin{array}{l}-0.343 \\
(0.505)\end{array}$ & $\begin{array}{l}-0.339 \\
(0.466)\end{array}$ & $\begin{array}{l}-0.358 \\
(0.526)\end{array}$ & $\begin{array}{c}-1.101^{* *} \\
(0.526)\end{array}$ & $\begin{array}{c}-1.175^{* *} \\
(0.509)\end{array}$ & $\begin{array}{l}-0.746 \\
(0.466)\end{array}$ \\
\hline Oil rent/GDP & $\begin{array}{c}0.371^{* * *} \\
(0.115)\end{array}$ & $\begin{array}{c}0.313^{* *} \\
(0.134)\end{array}$ & $\begin{array}{c}0.378^{* * *} \\
(0.120)\end{array}$ & $\begin{array}{l}0.0739 \\
(0.177)\end{array}$ & $\begin{array}{c}0.103 \\
(0.174)\end{array}$ & $\begin{array}{l}0.0173 \\
(0.163)\end{array}$ \\
\hline Terms of Trade & $\begin{array}{c}0.0966^{*} \\
(0.0551)\end{array}$ & $\begin{array}{l}0.0938^{*} \\
(0.0515)\end{array}$ & $\begin{array}{l}0.0961^{*} \\
(0.0553)\end{array}$ & $\begin{array}{c}0.0459 \\
(0.0543)\end{array}$ & $\begin{array}{l}0.00846 \\
(0.0664)\end{array}$ & $\begin{array}{c}0.0636 \\
(0.0477)\end{array}$ \\
\hline Share young & $\begin{array}{c}0.0261 \\
(0.0421)\end{array}$ & $\begin{array}{c}0.0139 \\
(0.0430)\end{array}$ & $\begin{array}{c}0.0339 \\
(0.0490)\end{array}$ & $\begin{array}{c}0.184^{* * *} \\
(0.0653)\end{array}$ & $\begin{array}{l}0.110^{* *} \\
(0.0554)\end{array}$ & $\begin{array}{c}0.187^{* * *} \\
(0.0653)\end{array}$ \\
\hline Share old & $\begin{array}{c}0.0442 \\
(0.0986)\end{array}$ & $\begin{array}{l}-0.0602 \\
(0.0983)\end{array}$ & $\begin{array}{l}-0.0708 \\
(0.0941)\end{array}$ & $\begin{array}{c}-0.0134 \\
(0.108)\end{array}$ & $\begin{array}{l}0.0395 \\
(0.113)\end{array}$ & $\begin{array}{c}0.0730 \\
(0.0985)\end{array}$ \\
\hline Econ. growth & $\begin{array}{c}-0.0891 \\
(0.146)\end{array}$ & $\begin{array}{l}-0.0659 \\
(0.151)\end{array}$ & $\begin{array}{l}-0.0750 \\
(0.155)\end{array}$ & $\begin{array}{c}-0.778^{* * *} \\
(0.237)\end{array}$ & $\begin{array}{c}-0.786^{* * *} \\
(0.256)\end{array}$ & $\begin{array}{c}-0.630^{* * *} \\
(0.186)\end{array}$ \\
\hline Pr. credit/GDP & $\begin{array}{l}-0.00161 \\
(0.00978)\end{array}$ & $\begin{array}{c}-0.00895 \\
(0.0101)\end{array}$ & $\begin{array}{r}-0.00288 \\
(0.0113)\end{array}$ & $\begin{array}{c}-0.00624 \\
(0.0118)\end{array}$ & $\begin{array}{l}-0.0132 \\
(0.0113)\end{array}$ & $\begin{array}{l}-0.0186 \\
(0.0117)\end{array}$ \\
\hline Gov. deficit/GDP & $\begin{array}{c}0.388^{* * *} \\
(0.0783)\end{array}$ & $\begin{array}{c}0.411^{* * *} \\
(0.0715)\end{array}$ & $\begin{array}{c}0.378^{* * *} \\
(0.0779)\end{array}$ & $\begin{array}{c}0.416^{* * *} \\
(0.0854)\end{array}$ & $\begin{array}{c}0.469^{* * *} \\
(0.0833)\end{array}$ & $\begin{array}{c}0.484^{* * *} \\
(0.0754)\end{array}$ \\
\hline Openness & $\begin{array}{c}0.0110 \\
(0.0107)\end{array}$ & $\begin{array}{c}0.0255^{* *} \\
(0.0106)\end{array}$ & $\begin{array}{l}0.0218^{*} \\
(0.0131)\end{array}$ & $\begin{array}{c}0.0442^{* * *} \\
(0.0129)\end{array}$ & $\begin{array}{c}0.0567 * * * \\
(0.0117)\end{array}$ & $\begin{array}{c}0.0543^{* * * *} \\
(0.0110)\end{array}$ \\
\hline Constant & $\begin{array}{l}-3.424 \\
(5.917)\end{array}$ & $\begin{array}{l}-2.607 \\
(8.610)\end{array}$ & $\begin{array}{l}1.053 \\
(5.938)\end{array}$ & $\begin{array}{l}15.35 \\
(11.02)\end{array}$ & $\begin{array}{c}3.492 \\
(10.75)\end{array}$ & $\begin{array}{l}19.55^{*} \\
(10.39)\end{array}$ \\
\hline Observations & 360 & 360 & 355 & 175 & 175 & 174 \\
\hline R-squared & 0.635 & 0.650 & 0.637 & 0.795 & 0.796 & 0.818 \\
\hline
\end{tabular}

Note: This table reports the coefficients and their standard errors for model (4) estimated by Pooled OLS-IV where the network variable (Network) included is stat2B in the top of Columns (1)-(3) for ITN and Columns (4)-(6) for IFN, respectively. The fiscal balance is instrumented by unemployment rate, average country's fiscal balance over time, and polity index. $* * *, * *$, and $*$ indicate significance at $1 \%, 5 \%$, and $10 \%$. 
Finally, the results presented in Table 7 can be used to evaluate the impact of international networks on the current account during the crisis episodes. There were a number of financial crises of various magnitude that affected various economies during the last two decades (see Ductor and Grechyna, 2015). The financial crisis of 2008-2009 is the most universal among these episodes, as its consequences spread over the global economy. The global current account imbalances have been considered as one of the reasons behind the recent financial crisis of 2008-2009 (Chinn et. al., 2013). At the same time, a better position in the international networks can soften the impact of financial crises on a given country's economy (see, for example, Chinazzi, Fagiolo, Reyes, and Schiavo, 2013). The results suggest that while the ITN centrality measures had insignificant impact on the current account, a higher IFN degree or strength led to improvement in the current account balance during the Great Recession, following the financial crisis and observed during the period around 2008-2011. This is, again, the evidence that the risk-diversification channel can be more effective than the spillovers-from-partners channel of the international networks' impact on the current account.

\section{Conclusions}

This paper analyzes the impact of the international trade and financial networks on the current account balances in a large sample of developed and developing countries. First, the theories of the current account balance and the role of international networks in these theories are discussed. The impact of international networks on the current account is ambiguous in general, because a country with a better position in the international network can better diversify domestic and international risks but at the same time it is disposed to more international shocks.

Second, following the networks literature, a country's importance in the international networks is measured by the number of links or the volumes of trade or financial flows between a country and its trading partners, as well as by the importance of a country in connecting other countries in the network.

Third, the empirical model relating the current account balance to the international network centrality of a country is estimated. The results obtained from pooled OLS estimations and from the estimations accounting for potential endogeneity of the network variables and the fiscal balance suggest that a more central position in the international trade or financial network improves the current account balance in developed and developing countries. A more central position in the international trade network as measured by degree centrality improves the 
current account balance in developed countries but can worsen the current account balance in developing countries.

Finally, the impact of international and financial networks on current account over time is analyzed, including the Great Recession period following the financial crisis of 2008-2009. The results indicate that the international financial networks have become a more important driver of the current account balance during the last two decades, while the impact of the international trade networks remained constant for developed countries, and decreased over time for developing countries.

\section{References}

[1] Aizenman, J. and Jinjarak, Y., 2009. Current account patterns and national real estate markets. Journal of Urban Economics, 66(2), pp.75-89.

[2] Alfaro, L., Kalemli-Ozcan, S. and Volosovych, V., 2014. Sovereigns, upstream capital flows, and global imbalances. Journal of the European Economic Association, 12(5), pp.1240-1284.

[3] Allen, F. and Gale, D., 2000. Financial contagion. Journal of political economy, 108(1), pp.1-33.

[4] Aller, C., Ductor, L. and Herrerias, M.J., 2015. The world trade network and the environment. Energy Economics, 52, pp.55-68.

[5] Barbieri, Katherine and Omar M. G. Keshk. 2016. Correlates of War Project Trade Data Set Codebook, Version 4.0. Online: http://correlatesofwar.org.

[6] Barbieri, Katherine, Omar M. G. Keshk, and Brian Pollins. 2009. TRADING DATA: Evaluating our Assumptions and Coding Rules. Conflict Management and Peace Science. 26(5): 471-491.

[7] Behringer, J. and van Treeck, T., 2018. Income distribution and the current account. Journal of International Economics, 114, pp.238-254.

[8] Bernanke, B., 2005. The global saving glut and the US current account deficit (No. 77). Board of Governors of the Federal Reserve System (US).

[9] Bramoulle, Y., Djebbari, H. and Fortin, B., 2009. Identification of peer effects through social networks. Journal of econometrics, 150(1), pp.41-55. 
[10] Ca'Zorzi, M., Chudik, A. and Dieppe, A., 2012. Thousands of models, one story: Current account imbalances in the global economy. Journal of International Money and Finance, 31(6), pp.1319-1338.

[11] Caballero, R. J., Farhi, E., \& Gourinchas, P. O., 2008. An Equilibrium Model of "Global Imbalances" and Low Interest Rates. American Economic Review, 98(1), 358-393.

[12] Calderon, C.A., Chong, A. and Loayza, N.V., 2002. Determinants of current account deficits in developing countries. Contributions in Macroeconomics, 2(1).

[13] Chinazzi, M., Fagiolo, G., Reyes, J.A. and Schiavo, S., 2013. Post-mortem examination of the international financial network. Journal of Economic Dynamics and Control, 37(8), pp.1692-1713.

[14] Chinn, M.D., Eichengreen, B. and Ito, H., 2013. A forensic analysis of global imbalances. Oxford Economic Papers, 66(2), pp.465-490.

[15] Chinn M. D., Ito H., 2007. Current account balances, financial development and institutions: Assaying the world "saving glut". Journal of International Money and Finance, 26 (4): 546-569.

[16] Chinn, M. Prasad, E., 2003. Medium-Term Determinants of Current Accounts in Industrial and Developing Countries: An Empirical Exploration. Journal of International Economics, 59(1): 47-76.

[17] De Benedictis, L. and Tajoli, L., 2011. The world trade network. The World Economy, 34(8), pp.1417-1454.

[18] Ding, H., Jin, Y., Liu, Z. and Xie, W., 2019. The relationship between international trade and capital flow: A network perspective. Journal of International Money and Finance, 91, pp.1-11.

[19] Ductor, L. and Grechyna, D., 2015. Financial development, real sector, and economic growth. International Review of Economics and Finance, 37, pp. 393-405.

[20] Fagiolo, G., Reyes, J., and S. Schiavo, 2009. World-trade web: Topological properties, dynamics, and evolution. Physical Review E, Vol. 79(3), pp. 7933.

[21] Fagiolo, G., Reyes, J., and S. Schiavo, 2010. The evolution of the world trade web: A weighted network analysis. Journal of Evolutionary Economics, Vol. 20(4), pp. 479-514. 
[22] Fratzscher, M. and Straub, R., 2009. Asset prices and current account fluctuations in G-7 economies. IMF Staff Papers, 56(3), pp.633-654.

[23] Gai, P. and Kapadia, S., 2010. Contagion in financial networks. Bank of England. Quarterly Bulletin, 50(2), p.124.

[24] Glick, R. and Rose, A.K., 1999. Contagion and trade: Why are currency crises regional?. Journal of international Money and Finance, 18(4), pp.603-617.

[25] Gruber, J.W. and Kamin, S.B., 2007. Explaining the global pattern of current account imbalances. Journal of international money and Finance, 26(4), pp.500-522.

[26] Gruber, J. and Kamin, S., 2009. Do differences in financial development explain the global pattern of current account imbalances?. Review of International Economics, 17(4), pp.667688.

[27] Kali, Raja, and Javier Reyes, 2010. Financial contagion on the international trade network. Economic Inquiry 48, no. 4: 1072-1101.

[28] Lane, P.R. and Milesi-Ferretti, G.M., 2018. The external wealth of nations revisited: international financial integration in the aftermath of the global financial crisis. IMF Economic Review, 66(1), pp.189-222.

[29] Lucas, R.E., 1990. Why doesnt capital flow from rich to poor countries?. American Economic Review, 80(2), pp.92-96.

[30] Minoiu, Camelia, and Javier A. Reyes, 2013. A network analysis of global banking: 19782010. Journal of Financial Stability 9, no. 2: 168-184.

[31] Nier, Erlend, Jing Yang, Tanju Yorulmazer, and Amadeo Alentorn, 2007. Network models and financial stability. Journal of Economic Dynamics and Control 31, no. 6: 2033-2060.

[32] Obstfeld, M. and Rogoff, K., 1995. The intertemporal approach to the current account. Handbook of international economics, 3, pp.1731-1799.

[33] Ranciere, R., Throckmorton, M.N.A., Kumhof, M.M., Lebarz, M.C. and Richter, M.A.W., 2012. Income inequality and current account imbalances (No. 12-18). International Monetary Fund.

[34] Schiavo, Stefano, Javier Reyes, and Giorgio Fagiolo, 2010. International trade and financial integration: a weighted network analysis. Quantitative Finance 10, no. 4: 389-399. 


\section{a PREVIOUS WORKING PAPERS IN THE SERIES}

Socioeconomic Correlates of Political Polarization: Evidence from English Counties.

Daryna Grechyna

Nudging responses to marketing emails: Evidence from London Fireworks Campaign.

Alice Gimblett and Daryna Grechyna

Mandatory Spending, Political Polarization, and Macroeconomic Volatility.

Daryna Grechyna

Conformity and truthful voting under different voting rules.

Bernardo Moreno, Maria del Pino Ramos-Sosa, and Ismael Rodriguez-Lara

On how to allocate the fixed cost of transport networks.

Teresa Estan, Natividad Llorca, Ricardo Martinez, and Joaquin Sanchez-Soriano

Multilevel proficiency comparisons with an application to educational outcomes in PISA.

Ricardo Martinez and Antonio Villar

Population structure and the human development index.

Carmen Herrero, Ricardo Martinez, and Antonio Villar

From Financial to Managerial Capitalism. The slow adaptation of Spanish corporate elite Downloads.

Juan A. Rubio Mondejar, Josean Garrues Irurzun and Luis Chirosa

Sequential Common Consequence Effect and Incentives Downloads.

Maria J. Ruiz-Martos

The Fiscal and Welfare Consequences of the Price Indexation of Spanish Pensions.

Julian Diaz Saavedra

Allocating the costs of cleaning a river; estimating responsibilities versus incentive compatibility.

Jorge Alcalde-Unzu, Maria Gomez-Rua and Elena Molis 